Portland State University

PDXScholar

Center for Public Service Publications and

Reports

Center for Public Service

2-2012

\title{
Capacity Building for the Common Good: PSU's Interdisciplinary Minor in Civic Leadership
}

\author{
Masami Nishishiba \\ Portland State University, nishism@pdx.edu \\ Kevin Kecskes \\ Portland State University, kecskesk@pdx.edu
}

Follow this and additional works at: https://pdxscholar.library.pdx.edu/publicservice_pub

Part of the Curriculum and Instruction Commons, and the Higher Education Commons Let us know how access to this document benefits you.

\section{Citation Details}

Masami Nishishiba \& Kevin Kecskes (2012) Capacity Building for the Common Good: PSU's Interdisciplinary Minor in Civic Leadership, Journal of College and Character, 13:1.

This Article is brought to you for free and open access. It has been accepted for inclusion in Center for Public Service Publications and Reports by an authorized administrator of PDXScholar. Please contact us if we can make this document more accessible: pdxscholar@pdx.edu. 


\title{
Journal of College \& Character
}

VOLUME 13, No. 1, February 2012

\section{Capacity Building for the Common Good: PSU's Interdisciplinary Minor in Civic Leadership ${ }^{1}$}

\author{
Masami Nishishiba, Portland State University \\ Kevin Kecskes, Portland State University ${ }^{2}$
}

\begin{abstract}
Since the early 1990s, Portland State University has furthered its commitment to civic engagement education by adopting an integrated approach to its general education curriculum. As an outgrowth to this initiative, the minor in Civic Leadership was developed in 2004-05. This interdisciplinary minor was designed with the intent to further integrate and sustain institutional engagement with the Portland Metropolitan community and beyond. This article discusses the history, structure, and roles of academic and community partners associated with the Civic Leadership minor, and elaborates the philosophical foundation of the interdisciplinary curriculum that aims to build student capacity for the common good.
\end{abstract}

critical role of higher education is to prepare students to live and work in interdependent and ever-changing global environments. Students in today's complex world must develop a high level of civic literacy and critical thinking skills to lead in a power-shared world. They must be able to make intellectual and moral decisions and take action for the common good (Ehrlich, 2000; Morgan, Green, Shinn, \& Robinson, 2008; Newell \& Davis, 1988). Leadership of this type requires development of traditional management skills such as planning, coordinating, and directing; it also requires an additional set of skills that include collaborative decision making, deal brokering, and resources bridging. This boundary-spanning leadership requires actors to work among undefined structures with loosely coupled groups of participants, assist them in creating a sense of shared meaning, and support them in maintaining direction. The effectiveness of the leadership depends on circumstances or elements outside of one's control and on the willing cooperation of others working in concert (Miller, 2008, 2009).

At Portland State University (PSU), a minor in Civic Leadership was developed covering broad disciplinary domain from liberal arts and social science to hard science; this requires an all-hands-on-deck strategy among faculty to ensure that students' experiences include leadership challenges from multiple points of view and work with diverse groups of college and community partners informed by varied social and disciplinary perspectives. The purpose of this essay is

1 The authors thank Douglas Morgan, Sherril Gelmon, Barry Messer, and Amy Spring for sharing their insights about the Civic Leadership minor. We also thank Patrice Morris Hudson for reviewing the manuscript.

2 Masami Nishishiba is assistant professor of public administration and associate director for the Center for Public Service at the Hatfield School of Government, Portland State University. She coordinated the Civic Leadership minor from 2004 to 2010. Kevin Kecskes is associate vice provost for engagement and director for community-university partnerships at Portland State University. Kecskes was one of the original architects of the academic minor and teaches civic leadership in the Hatfield School of Government Division of Public Administration. 
to outline the philosophical underpinnings and the strategies that shaped the development and implementation of the curriculum that aims to foster civic leadership among students and to document and capture lessons learned from PSU's experience.

The development and implementation of PSU's minor in Civic Leadership are guided by the following seven principles: (a) curriculum for civic leadership development should adopt a broad definition of citizenship; (b) community-based learning $(\mathrm{CBL})^{3}$ is a critical pedagogical strategy for civic leadership development; (c) curriculum for civic leadership development should be interdisciplinary; (d) CBL courses for civic leadership should be appropriately sequenced to match students' developmental stages and help connect common civic outcomes embedded within the various majors that participate in the program; (e) a community-university partnership approach is essential for civic leadership development; (f) acknowledgment that curriculum development is a constantly evolving, ongoing process; and (g) integration of liberal arts and professional education is important for civic leadership development.

First, in developing the Civic Leadership minor we recognized the importance of defining good citizenship terms broadly. Good citizens not only participate in the formal political process, but are also involved in various voluntary organizations that contribute to the public good of the community. In their essay, Boyte and Farr (1997) described three main conceptions of citizenship identified in American history:

- rights-bearing members of a political system who choose their leaders, preferably men of distinctive virtue and talent, through elections,

- caring members of a moral community who share certain values and feel common responsibilities toward one another, and

- practical agents of a civic world who work together in public ways and spaces to engage the tasks and try to solve the problems that they collectively face. (p. 37)

Good citizenship behavior under the first conception of citizenship entails mainly voting, petitioning for grievances, and perhaps organizing with others to express their interest. The second conception of citizenship promotes communitarian behavior that serves one another, but especially those who are in need. Good citizens, understood within the context of the third conceptual frame, work collaboratively through deliberation and engage in problem solving to promote public good. In developing curriculum for civic leadership, one needs to embrace all three conceptions of citizenship.

The second principle of PSU's civic leadership curriculum development is the identification of CBL pedagogical approaches as the key component. We aspire to incorporate CBL in all courses. As the literature on college student leadership education suggests, community-based experiential learning is one of the salient factors in students' capacity development (Cress, Astin, ZimmermanOster, \& Burkhardt, 2001; Dugan \& Komives, 2010; Eich, 2008; Thompson, 2006). In the civic leadership development domain, skills associated with "the public arena where one engages in the affairs of the society, through public advocacy, debate, education, and fostering of dialogue and group reflection" (Azzam \& Riggio, 2003, p. 55) are required. It is even more important that students work on actual community problems and issues so they can develop deeper understandings of broader real world contexts.

${ }^{3}$ In the 1990s, Portland State University faculty chose to use the term "community-based learning (CBL)" instead of the then more commonly used term "service-learning"; thus, the authors will refer to PSU's community engaged curricular strategy as CBL. 
The third principle addresses the importance of interdisciplinary curriculum in civic leadership education. Civic leadership should not be viewed merely from the traditional perspectives of political science, business, or public administration. Rather, we posit that it is vital for students in all disciplines to have multiple active opportunities to consider the public purposes of their discipline, ideally through developmental CBL experiences embedded within the major. Real-world issues are interdisciplinary. They do not follow artificial boundaries established within traditional academic disciplines. For students to develop skills to address real-world social issues, they will need education that integrates insights from multiple disciplines. Interdisciplinary programs with problem-centered CBL experiences prepare students to make judgments on complex issues and take actions to solve complex social problems (Newell \& Davis, 1988).

The fourth principle states that, to develop civic leadership, curriculum needs to be appropriately sequenced so it will span across well-established college student developmental stages. Attention also should be paid to how the civic leadership courses fit within majors of the associated academic program. In the college curriculum development literature, relatively little attention has been given to the importance of course sequencing and the students' developmental readiness with community-based experiences (Flanagan, 2004). There are, however, studies that suggested community-based experiences have different impact for different age groups of students, which indicates the importance of deliberately sequencing the curriculum to match students' developmental stages (Eccles et al., 2002; Melchior \& Abt Associates, 1998).

The fifth principle places a community-university partnership approach as a critical component of the civic leadership curriculum. Good citizenship can best be cultivated by developing strong partnerships with community organizations that provide students with meaningful CBL/civic involvement experiences to help them practice and learn specific community leadership skills that are otherwise unavailable in the classroom alone. Further, there is recognition of the attendant epistemological challenges and opportunities that arise when it is acknowledged that there are important and multiple sources of wisdom and knowledge associated with key pieces of the intellectual and practical/skill building aspects of the minor (Azzam \& Riggio, 2003; Newell \& Davis, 1988). This community-university partnership approach poses a new challenge to the faculty involved in the transmission of the courses. Contrary to traditional academic training, where intellectual content and most of the delivery of the content of the course is delivered by the faculty member in controlled, classroom-based environments, the pedagogy of partnerships can often require faculty members to relinquish some level of control over the learning process. Most effective partnership approaches to teaching and learning view all stakeholders (including students and community partners) as coteachers and co-learners along a dynamic learning continuum (Eich, 2008). Although this approach runs counter to a more traditional view of the academic as the "expert" in the civic leadership curriculum, we adopted community-university partnership as the core element of the curriculum.

Principle six represents our understanding that academic curriculum development is an ever-evolving, ongoing process rather than a one-time exercise. Curriculum development is a continuous process (e.g., Wiles, 2009; Wolf \& Christensen Hughes, 2007). Dynamic curricula require a systematic review and continual evaluation of the process and outcomes; modifications need to be regularly tested and implemented in order to improve the overall outcomes of the academic program.

The seventh principle recognizes the importance of having a collaborative approach between liberal arts general education and professional education for the purposes of civic leadership development. There are two types of conflicting concerns expressed about undergraduate education. One is a concern about the practical relevance of traditional liberal arts education, suggesting it does not prepare students for the challenges they face as professionals in an increasingly complex world. Another concern is that the public demand for education with practical relevance will minimize the liberal arts education to vocational training (Peach, 2010; Sullivan \& Rosin, 2008). We posit 
that good citizenship is most likely to be cultivated when students see a connection between their liberal arts education and their development as professionals. We agree with Sullivan and Rosin (2008) that curricula offered in collaboration between liberal arts and professional school faculty can address the need for students' skills development relevant to their professional demand, and at the same time provide students with foundational theoretical and philosophical knowledge that allow them to understand the importance of public good. This principle undergirds the decision to intentionally incorporate courses both from liberal arts and the professional schools in the academic program.

The seven principles outlined above are both philosophical and pragmatic, based largely on our experiences inside and outside of the university. Philosophically, we argue that every student, in every major, has the potential to develop into an effective civic leader should she or he have inclination to do so. Further, it is incumbent on the faculty to thoughtfully and creatively integrate civic-minded experiences into multiple courses within the discipline as a way to reflect upon and transmit the public purposes of their discipline in addition to the time-honored content of the domain. Pragmatically, personal experience has taught us that effectively addressing complex community issues will require creative, multidisciplinary, integrated approaches. Therefore, providing students (our future civic leaders) with opportunities to learn in enriched, real-time environments within the context of interdisciplinary teams, where they must learn to appreciate and assimilate multiple points of view, makes the most sense in terms of providing students with useful experiences and skill-building opportunities.

Three specific strategies were adopted in developing a Civic Leadership minor curriculum that fosters students' capacity to become effective civic leaders. In the development of the civic leadership curriculum we (a) created an integrated academic pathway focusing on good citizenship, (b) expanded broadly a civic responsibility approach via CBL throughout multiple colleges within the university, and (c) furthered institutionalizing the university's social responsibility mission by creating a formal academic program.

The first strategy we adopted was to focus on providing students with courses from multiple disciplines, sequenced as a pathway toward developing future leaders with civic commitment. Review of existing curriculum at PSU prior to the creation of the Civic Leadership minor suggested that there was no integrated academic pathway for students to study the role and function of their sense of social responsibility. Therefore, we created the academic program to fill a void in the university's curriculum. The second strategic step we took was to identify existing CBL courses that were already offered as part of the major offerings and are suitable for civic leadership development and integrated them into the minor curriculum. Inclusion of these CBL courses into an interdisciplinary academic program elevated the status of these courses and helped faculty members incorporate their interest in civic leadership into their courses. We also expanded some CBL offerings by encouraging faculty members who teach courses in the Civic Leadership minor to include CBL components. We employed this strategy to both expand and deepen CBL opportunities for students, not only for the students in the minor but also for students directly tied to the academic work in the majors. The overarching goal is to continue to transform departmental thinking toward a deeper embrace of applied and community-connected curricular and research activities (Kecskes, 2006, 2011). The third strategy we adopted was to "formalize" the curriculum as a "minor." Instead of offering the civic leadership curriculum as a suggested "track" within general education, for example, we intentionally made the curriculum an academic program housed in an academic department. Once established, academic programs are hard to discontinue; thus we chose this strategy as the best approach to institutionalize the curriculum for civic leadership development.

In the next section we will (a) outline the history and development of PSU's minor in Civic Leadership, (b) discuss its structure and operation, (c) share challenges and insights, and (d) consider future directions for the program and for these efforts nationally. 


\section{PSU's Minor in Civic Leadership: History and Development}

$\mathrm{T}$ his minor builds on the university's service mission that has been institutionalized in both the University Studies (general education) program and the broader efforts to build partnerships with local community organizations and political entities within the region. This minor deepens and further integrates the university's commitment to sustained institutional engagement with the Portland Metropolitan community and beyond. The specific stated objectives include

- Provide students with a curricular opportunity to pursue a secondary interest in community and public service while completing their major requirements.

- Address the growing national concern about the decline in civic engagement and political participation on the part of the current generation of college graduates.

- Expand and deepen University partnerships with community organizations and political entities within the larger Metropolitan region.

In 1994, PSU inaugurated a new general education model called "University Studies." This model consists of Freshman Inquiry (15 credits), Sophomore Inquiry (12 credits), Junior Cluster (12 credits), and Senior Capstone (6 credits). Freshman Inquiry is a year-long sequence of interdisciplinary courses that introduces students to PSU's general education curriculum. Sophomore Inquiry courses are gateway classes for content to be further explored in the Junior Cluster. Each of the Sophomore Inquiry courses is aligned to a particular cluster. Upon completion of three Sophomore Inquiry classes, students select a cluster for their junior year. Junior Cluster options comprise courses from a variety of disciplines based on a theme. There are more than a dozen clusters offered. Senior Capstone is a culmination course for the University Studies curriculum. Each capstone course is structured around a specific (set of) community issue(s); students from a variety of majors work as an interdisciplinary team to addresses the community-identified concern. Capstone courses provide opportunities for students to actively learn about communication, teamwork, diversity, and social responsibility through this mandatory six-credit CBL course. In academic year 2010-11, there were over 3,600 students engaged in approximately 260 capstone courses (PSU, University Studies, 2011). Although culminating experiences connected to the curriculum are now relatively commonplace in American higher education, very few institutions offer interdisciplinary, themebased capstone experiences (Kecskes \& Kerrigan, 2009). Despite, or perhaps because of, PSU's integrated and community-connected general education curriculum, students regularly search for more academic work that is community-based. The motivation to meet students' desires for more community engagement, along with the other principles and strategic considerations mentioned earlier, led to the development of the Civic Leadership minor.

An important antecedent to the Civic Leadership minor is a series of Fund for the Improvement of Post-Secondary Education (FIPSE) efforts to develop courses at PSU that intentionally foster civic mindedness and leadership among students. The Civic Capacity Initiative: Integrating Liberal Arts and Professional/Career Education Program was awarded a 3-year grant in 2000. The primary purpose of the FIPSE grant was to restructure the existing "Leadership for Change" Sophomore Inquiry and Junior Cluster and to develop courses that were designed specifically to increase the capacity and interest among students to become more active in civic and public life (Williams, Shinn, Nishishiba, \& Morgan, 2002).

Under the FIPSE grant project, 13 new courses were developed with the intention to achieve the following three goals: (a) better integrate liberal arts with professional and career education through curriculum design and faculty and community collaborations, (b) inculcate a heightened sense of civic responsibility among undergraduate and graduate students by strengthening PSU's 
institutional ethos of civic engagement, and (c) deepen and broaden the university's relationship with partners in the larger external community.

This effort resulted in the design or redesign of 19 courses that are permanently part of the university curriculum. It built lasting collegial relationships between and within departments and schools across campus and strategic community partners. The FIPSE project trained a cadre of Ph.D. students who today carry forward their own civic engagement agendas. Finally, the effort heightened the awareness within the university of the important role curricular development plays in the education of students for citizenship. The course development work undertaken by FIPSE played an influential role in the creation of the Civic Leadership minor in two significant ways: (a) Many courses developed under the FIPSE grant were included in the minor, providing a curricular focus for students who have a broad interest in civic leadership and community engagement, and (b) the interdepartmental, cross-school work in collaboration with students and community partners inspired us to believe that working across departments and schools was worth the opportunity costs and could actually work.

\section{Structure and Operation of the Civic Leadership Minor}

$\mathrm{T}$ he Civic Leadership minor consists of 34 required credit hours drawn from 26 course options that are embedded in nine different departments and located across three colleges at PSU (see PSU College of Urban \& Public Affairs, Hatfield School of Government, 2011). The minor is intended to create a curricular focus for students who have a broad general interest in civic leadership and community engagement. The minor features several specific programmatic elements including:

- Introductory, foundations course with rigorous civic leadership and community engagement components, which are tied to a final integrative seminar;

- Long-term, focused engagement via community partnership;

- Final integrative/reflective seminar, which culminates in a professional portfolio presentation;

- Intentionally connected community-based practicum requirements;

- Recognition and integration of multidisciplinary approaches to civic engagement and leadership development;

- Balanced attention given to both theoretical understanding and practical civic skill building;

- Broad, nonhierarchical presentation of "leadership," including the recognition and integration of emerging political challenges to re-engage citizens in public life and democratic governance.

\section{Course Sequence}

Conceptually, the minor was designed with the idea that courses would be taken sequentially. However, as we will later discuss in the "challenges" section, we have learned that PSU students often follow curricular pathways that deviate from the design. Ideally, students would first take an introductory course (PA311: Introduction to Civic Leadership) in the early part of their academic career and the final integrative, reflective seminar (PA 415: Civic Leadership Integrative Seminar) as the last course for their minor. The introductory course provides students with theoretical foundations of civic leadership in a rigorous CBL setting that experientially introduces students directly to community issues and leadership responses. The final integrative seminar aims to 
integrate students' civic leadership learning; the seminar features the development and presentation of a professional portfolio of students' civic lives: past, present, and future.

Between the introductory course and the final integrative seminar, students take 5 electives from a list of 26 courses. These courses are intentionally selected from multiple departments in different colleges to reflect multidisciplinary perspectives on civic leadership. These elective courses emphasize both theoretical and practical civic skills and leadership development. Many of the courses developed as part of the FIPSE grant initiative are included as elective courses.

\section{Academic Home}

The Civic Leadership minor is housed in the Division of Public Administration in the Mark O. Hatfield School of Government. The decision to house the minor in the Division of Public Administration, which is a graduate professional school, reflects our principle regarding the importance of making connections between professional schools and liberal arts curriculum for the purpose of promoting "good citizenship" education.

The curriculum development, however, was a joint effort between faculty from the Center for Academic Excellence (CAE) and the Division of Public Administration. Faculty in PSU's CAE, specifically the division of Community-University Partnerships, which houses universitywide information on CBL courses and has extensive connections with multiple community partners, took the lead in compiling the list of multidisciplinary courses with community-based components.

\section{Long-Term Community Partnership}

Building from insights borne from PSU's 14-year, national award-winning "Community Watershed Stewardship Partnership" efforts (PSU Center for Academic Excellence, 2011b), faculty involved with building the minor's introductory course (PA 311, Introduction to Civic Leadership) chose to implement a long-term partnership development strategy. The essence of this effort is based on institution-to-institution partnership with multiple and diverse iterations at the grounded community level. The community partner in this case is the City of Portland (Messer \& Kecskes, 2008, 2010). The importance of establishing a long-term partnership is also supported by the work at the University of Minnesota with the Jane Addams Community School (Wallace, 2000).

Faculty who developed the introductory course chose to work specifically with the Office of Neighborhood Involvement (ONI) within the City of Portland, Oregon. Portland has a unique and robust set of neighborhoods that have a semiautonomous governance structure and are supported by ONI housed in City Hall (De Morris \& Leistner, 2009). There were several key advantages to working with ONI: (a) Although projects necessarily change from term to term and over the years, the primary institution-to-institution partnership between the faculty in the department and the city office endures; (b) as a central coordinating and funding office, ONI is regularly in touch with 30+ neighborhood-based projects at any given time; ONI staff have a solid sense of the trajectory of the various community projects and the principal community actors as well, and its position in relation to the neighborhood project puts it in a strategic position to suggest specific projects for classes to work with from term to term; (c) ONI needs the support, and carefully chosen communitybased neighborhood associations make fantastic partners for university students; (d) when problems occur, ONI is there to assist course faculty and neighborhood actors to quickly mitigate most issues; (e) neighborhood associations have much autonomy in development and implementation of their projects; often, they share that autonomy with the students and are generally quite welcoming of student input and action; and finally (f) many aspects of the neighbor-level projects that are otherwise not likely to be accomplished can be realized with the assistance of the students in the course. 


\section{Challenges and Insights}

\section{Coordination}

The implementation of the Civic Leadership minor has experienced challenges. The strengths and the unique features of the curriculum also posed some challenges in the execution. One of the challenges stemmed from the interdisciplinary nature of the curriculum. Unlike a curriculum with all the courses offered from within one academic department, this minor consists of courses from nine departments. Thus, consistent information sharing and regular coordination among these departments are needed to update the course offerings. Even ascertaining what courses are offered for the minor in a given term requires a great deal of work. The faculty coordinator must contact each department every term to determine which of the courses listed under the minor will be offered. Further, departments sometimes make changes in the course content and, accordingly, course names or course numbers change. The minor faculty coordinator needs to be informed of these changes and reflect the changes in the minor curriculum. Obtaining and updating course information from nine departments on an on-going basis is energy intensive and time consuming.

\section{Undergraduate Curriculum in a Professional School}

The minor is housed in the Division of Public Administration and Policy, a graduate-only professional school. Offering an undergraduate minor curriculum in a graduate program caused significant challenges in student recruitment. Due simply to the fact that the Division of Public Administration and Policy does not have an undergraduate major, the majority of undergraduate students are not very familiar, if at all, with the division. Consequently, student enrollment was very low in the early phases of implementation of the minor. Further, due to low enrollments a number of courses associated with the minor were cancelled or not scheduled. With the smaller number of courses offered the overall sense of presence of the minor in the minds of undergraduates turned out to be weak; enrollment in key courses entered into a negative spiral. It took some efforts on the part of key faculty members involved in the minor to reach out to the student body and actively recruit students. These key faculty members met with student advisors from student affairs and various departments, explained the minor, and asked the student advisor to introduce the minor to their students. Also, some key faculty members attended the university-wide Undergraduate Fair to advertise the minor to the students. After two years of effort, course enrollment began to increase toward more sustainable levels.

\section{Departmental Buy-In}

Another challenge of offering an undergraduate minor curriculum in a graduate-only professional school is in developing the sense of ownership and endorsement of the curriculum among the faculty members. At the time the minor was brought to the Division of Public Administration, full-time faculty members already had full course loads teaching graduate courses. Consequently, undergraduate courses in the division were all being taught by either an adjunct professor or doctoral students. This arrangement resulted in most of the regular faculty not being actively involved in the implementation and further development of the minor. Initially, the only regular faculty members who were actively involved in the minor were the faculty advisor (who advised students and provided administrative support) and the division chair, who oversees the overall course offerings for the division. Other than these two faculty, most of the faculty members maybe had only heard about the minor and did not have a sufficient sense of ownership in the curriculum. 


\section{Advising Challenge: Course Sequence}

As noted above, the minor incorporated an intentional "developmental" (or "sequential") design in its curriculum structure. The idea was to expose the students to the basic theories and concepts for civic leadership in the introductory course (PA 311: Introduction to Civic Leadership). Then students would take courses offered through different departments for their electives, take the community-based practicum courses, engage in their significant community-based learning project, and then take the final reflective seminar (PA 415 Civic Leadership Integrative Seminar). In practice, it has been very difficult to guide students to take the courses in the intended sequence. In most cases, students found out about the minor after they had taken some elective courses for their University Studies (general education) cluster requirements. They saw the merit of taking a few extra courses outside their major in order to obtain a minor in Civic Leadership. As a consequence, many students enrolled in the introductory course (PA 311) after they had completed some elective courses. In one instance, a student was frustrated to learn that she would be unable to take the introductory (PA311) course and the final seminar (PA 415) simultaneously.

In order to remedy the situation, the faculty coordinator for the minor tried her best to reach out to students as early as possible for advising. However, the interdisciplinary nature of the curriculum, and also the fact that the minor is housed in a department where there are no undergraduate majors, made advising difficult. The minor faculty coordinator solicited help from student advising staff from the various departments, and as a result, over time, the situation has improved significantly since the initial years of implementation.

\section{Resource Challenge}

As is the case with many state universities, PSU is also facing financial challenges. Consequently, departments are forced to make decisions on course offerings based on student enrollment. Courses with low student enrollment are either cancelled or the number of offerings are reduced. Some Civic Leadership minor courses suffered from low student enrollment and became targets for cancellation or reduction. Even the required courses for the minor (PA311 and PA415) were offered on a limited basis due to the low enrollment, which made it harder for the minor to expand the student base.

\section{The Leadership Challenge}

Although there is general commitment to the Civic Leadership minor among departmental chairs and select faculty of the nine academic units, two overarching issues present a significant leadership challenge: (a) Creating, communicating, and maintaining a shared vision for this academic program are a sizable challenge; in part, this is simply due to the fact that it is nearly impossible to get everyone, or even most of the key people, in the same room at the same time, and also, there are few institutional incentives for departments to collaborate; (b) Courses change, instructors change, and courses get cancelled. As discussed earlier, simply keeping up to date with these changes is difficult; the need for informing new instructors about how their course fits into the minor requires additional time. These leadership challenges are associated with the resource challenge mentioned earlier.

\section{Insights and Future Directions}

$\mathrm{D}$ espite the significant challenges outlined above, we remain committed to the idea that students from every major can and should have access to expressions of civic leadership from the 
perspective of their chosen discipline. Further, it is incumbent on the faculty to thoughtfully and creatively integrate civic-minded experiences into multiple courses within the discipline as a way to reflect upon and transmit the public purposes of their discipline in addition to the time-honored content of the domain. As instructors in the minor, we have learned that focusing students with quite diverse academic backgrounds on a common, compelling community issue can lead to accelerated cognitive and affective growth. We have seen creative responses to entrenched problems emerge; we have read numerous formal student testimonials about the positive power of these coordinated CBL experiences and the effects they have had on student thinking and outlook for their future. Several students who graduated with the minor have obtained employment in the public and/or nonprofit sector; often, they contact us or other PSU faculty in hopes of becoming formal community partners connected to engaged courses or research endeavors.

Unfortunately, we have not yet had the time to systematically assess the minor curriculum's impact on students' civic leadership skills. Of particular interest would be to examine how the student learning outcome was affected by the minor's seven principles, i.e., (a broad definition of citizenship, (b) CBL, (c) interdisciplinary curriculum, (d) course sequencing, (e) communityuniversity partnership, (f) ongoing curriculum improvement, and (g) integration of liberal arts and professional education.

The prevalence of CBL courses at PSU continues to grow. In academic year 2010-11, more than 12,500 students (out of a total student population of 29,000) participated formally in one or more CBL courses. PSU's Senior Capstone Program (University Studies, 2011) places over 3,500 students in 260+ formal CBL courses every year. It is safe to assume that the continued efforts to improve and deepen teaching and learning and community-university partnerships within the context of that program continues to exert an impressive impact on the overall PSU mission to "let knowledge serve the city" (Kecskes \& Kerrigan, 2009). Further, since the early 1990s PSU's institution-wide faculty development center, CAE (PSU Center for Academic Excellence, 2011a), has provided leadership and formal training for faculty interested in integrating CBL, community-based research, or other forms of community-engaged strategies into their professional portfolios (Kecskes, Collier, \& Balshem, 2006; Kecskes, Kerrigan, \& Patton, 2006; Kecskes, Spring, \& Lieberman, 2004). In this regard, we view the development, implementation, and institutionalization of the minor in Civic Leadership as complementary to these longer-term and broader institutional efforts to address its civic mission. Indeed, PSU's institutional mission for community engagement provides a large-scale vehicle in which the minor in Civic Leadership was able to emerge and easily find an intellectual home.

In retrospect, there are a few key design pieces we would maintain and some we would change should the opportunity arise to develop another academic program of this kind. In the future, we would make the following five changes. First, we would place the program in a discipline that has an established undergraduate curricular pathway. Second, we would maintain the interdisciplinary nature of the program but work with fewer departments. We note that working across colleges has not posed significant challenges, only working across departments has for the reasons outlined earlier. Third, we would consider hiring a graduate assistant or secure some other resource to support the faculty advisor. Fourth, we would work more closely with the chairs of the department to ensure that they, and specific faculty whom they choose, have earlier and repeated opportunities to help create a shared vision and implementation strategy for the program. Fifth, we would work with key student advising staff more rigorously and: (a) invite them to assist in the design of the program as appropriate, (b) determine student recruitment solutions from the outset, (c) implement the recruitment strategies, and (d) establish regular feedback loops from the diversity of disciplinebased advisors back to the home department faculty advisor who is ultimately responsible for administration of the academic program. 
Critical Civic Leadership minor component parts that we would maintain in the future would include: (a) maintaining the interdisciplinary nature of the program; (b) deepening the institutionto-institution community partnership; (c) encouraging students through formal assignments, discussion, and especially through CBL activities to bring their diverse disciplinary perspectives to bear via teamwork in classroom and community settings; (d) introducing a rigorous, class-wide CBL experience in the introductory course so students in the minor share that common experience; and finally (e) maintaining the highly personalized and reflective nature of the final reflective seminar while requiring students to formally present their professional civic leadership learning e-portfolios to peers, faculty, and community partners.

Although our efforts to build this academic program have been challenged throughout the process, we believe that our overarching goal of helping prepare students to live and work in interdependent and ever-changing global environments is being met. Indeed, it is a life-long learning process that enables one to effectively lead in a power-shared world. Yet, structuring the academic program as we have done - to be interdisciplinary and community-based from the outset-provides undergraduate students consistent opportunities to experience and practice both traditional management skills as well as collaborative decision-making leadership strategies. These boundary-spanning efforts are emergent, requiring students to work among undefined structures with loosely coupled groups of participants, assist them in creating a sense of shared meaning, and support them in maintaining direction. We have argued that civic (or public) leadership in this regard is the domain of all, thus requiring an all-hands-on-deck strategy among diverse faculty from multiple disciplines to ensure that students' experiences include leadership challenges from multiple points of view and the students are informed by varied social and disciplinary perspectives. This wide yet integrated approach to curricular development, although at times confusing and messy, helps insure that our students' educative experiences most closely mirror the reality of actual community members with whom they will work upon graduation.

\section{References}

De Morris, A. A., \& Leistner, P. (2009). From neighborhood association system to participatory democracy: Broadening and deepening public involvement in Portland, Oregon. National Civic Review, 98, 47-55.

Azzam, T., \& Riggio, R. (2003). Community based civic leadership programs: A descriptive investigation. Journal of Leadership \& Organizational Studies, 10(1), 55-67.

Boyte, H. C., \& Farr, J. (1997). The work of citizenship and the problem of service-learning. In R. M. Battistoni \& W. E. Hudson (Eds.), Experiencing citizenship: Concepts and models for service-learning in political science. Washington DC: American Association for Higher Education.

Cress, C. M., Astin, H. S., Zimmerman-Oster, K., \& Burkhardt, J. C. (2001). Developmental outcomes of college students' involvement in leadership activities. Journal of College Student Development, 42, 15-27.

Dugan, J. P., \& Komives, S. R. (2010). Influences on college students' capacities for socially responsible leadership. Journal of College Student Development, 51, 525-549.

Eccles, J. S., Gootman, J. A. (Eds.) (2002). Committee on Community-Level Programs for Youth, Board on Children, Youth, and Families, Division of Behavioral and Social Sciences and Education, National Research Council, \& Institute of Medicine. Community programs to promote youth development. Washington, DC: National Academy Press.

Ehrlich, T. (2000). Civic responsibility and higher education. Phoenix, AZ.: Oryx Press.

$\begin{array}{llll}\text { JCC NASPA } 2012 & \text { http://journals.naspa.org/jcc/ doi:10.1515/jcc-2012-1860 }\end{array}$


Eich, D. (2008). A grounded theory of high-quality leadership programs. Journal of Leadership \& Organizational Studies, 15(2), 176-187.

Flanagan, C. A. (2004). Volunteerism, leadership, poitical socializatin and civic engagement. In R. M. Lerner \& L. Steinberg (Eds.), Handbook of adolescent psychology, 2nd ed., (pp. 721745). Hoboken, NJ: John Wiley \& Sons.

Kecskes, K. (Ed.). (2006). Engaging departments: Moving faculty culture from private to public, individual to collective focus for the common good. Bolton, MA: Anker.

Kecskes, K. (2011). Engaged Departments Introduction. In J. Saltmarsh \& E. Zlotkowski (Eds.), Higher education and democracy: Essays on service-learning and civic engagement (pp. 251-255). Philadelphia, PA: Temple University Press.

Kecskes, K., Collier, P. J., \& Balshem, M. (2006). Engaging scholars in the scholarship of engagement. In K. McKnight Case, G. Davidson, S. H. Billig \& N. C. Springer (Eds.), Advancing knowledge in service-learning: Research to transform the field (pp. 159-181). Greenwich, $\mathrm{CT}$ : Information Age.

Kecskes, K., \& Kerrigan, S. (2009). Capstone experiences: Integrating education for civic engagement. In B. Jacoby (Ed.), Civic engagement in higher education (pp. 117-139). San Francisco, CA: Jossey-Bass.

Kecskes, K., Kerrigan, S., \& Patton, J. (2006). The heart of the matter: Aligning curriculum, pedagogy and engagement in higher education. Metropolitan Universities, 17(1), 51-61.

Kecskes, K., Spring, A., \& Lieberman, D. (2004). The Hesburgh Certificate and Portland State University's faculty development approach to supporting service learning and communityuniversity partnerships. To Improve the Academy, 22, 287-301.

Melchior, A., \& Abt Associates. (1998). National evaluation of Learn and Serve America school and community-based programs: Final report, prepared for the Corporation for National Service. Washington, DC: American Youth Policy Forum.

Messer, W. B., \& Kecskes, K. (2008). Social capital and community-university partnerships. In J. Dillard, V. Dujon, \& M. C. King (Eds.), Understanding the social dimension of sustainability (pp. 248-263). New York, NY: Routledge.

Messer, W. B., \& Kecskes, K. (2008). An anatomy of a community-university partnership: The structure of community collaboration. Journal of Higher Education, Outreach and Engagement, 12(3), 191-204.

Miller, P. M. (2008). Examining the work of boundary spanning leaders in community contexts. International Journal of Leadership in Education, 11(4), 353-377.

Miller, P. M. (2009). Boundary spanning in homeless children's education. Educational Administration Quarterly, 45(4), 616-630.

Morgan, D. F., Green, R., Shinn, C. W., \& Robinson, K. S. (2008). Foundations of public service. Armonk, NY: M.E. Sharpe.

Newell, W. H., \& Davis, A. J. (1988). Education for citizenship: The role of progressive education and interdisciplinary studies. Innovative Higher Education, 13(1), 27-37.

Peach, S. (2010). A curriculum philosophy for higher education: Socially critical vocationalism. Teaching in Higher Education, 15(4), 449-460.

Portland State University Center for Academic Excellence. (2011a). Welcome to the Center for Academic Excellence. Retrieved from http://www.pdx.edu/cae

Portland State University Center for Academic Excellence. (2011b). CWSP partnership wins engagement award. Retrieved from http://www.pdx.edu/cae/cwsp-wins-engagement-award

Portland State University College of Urban \& Public Affairs, Hatfield School of Government. (2011). Civic Leadership minor. Retrieved from http://www.pdx.edu/hatfieldschool/civicleadership-minor 
Portland State University University Studies (2011). Capstone. Retrieved from http://www.pdx.edu/unst/senior-capstone

Sullivan, W. M., \& Rosin, M. S. (2008). A new agenda for higher education: Shaping a life of the mind for practice. San Francisco, CA: Jossey-Bass.

Thompson, M. D. (2006). Student leadership process development: An assessment of contributing college resources. Journal of College Student Development, 47(3), 343-350.

Wallace, J. (2000). The problem of time: Enabling students to make long-term commitments to community-based learning. Michigan Journal of Community Service Learning, 7, 133141.

Wiles, J. (2009). Leading curriculum development. Thousand Oaks, CA: Corwin Press.

Williams, D., Shinn, C., Nishishiba, M., \& Morgan, D. F. (2002). Toward an understanding of civic capacity: An anatomy of community issues that matter to students. Journal of Public Affairs, 6(1), 241-264.

Wolf, P., \& Christensen Hughes, J. (2007). Curriculum development in higher education: Facultydriven processes and practices. San Francisco, CA: Jossey-Bass. 